\title{
SENSING OF VEGETATION STATUS USING ORTOPHOTOS IMAGE GENERATED WITH UAV
}

\section{Case study on Palm oil Plantation PTPN IV Siantar}

\author{
F Fahmi ${ }^{1}$, Sawaluddin ${ }^{2}$, U Andayani $^{2}$, B Siregar $^{2}$ \\ ${ }^{1}$ Dept. of Electrical Engineering, Faculty of Engineering, University of Sumatera Utara Jl. Dr. Mansur 9 \\ Medan Indonesia \\ ${ }^{2}$ Dept. of Information and Technology, Faculty of Computer Science and Information Technology, University \\ of Sumatera Utara Jl. Dr. Mansur 9 Medan Indonesia \\ Correspondence email: fahmimn@usu.ac.id
}

\begin{abstract}
Indonesia's growing area of cultivation and agriculture requires a monitoring system of growing vegetation on it. By using images captured from the top (orthophotos), the result was processed using algorithms of digital image processing combined with machine learning in order to get the accurate information of vegetation status. The long-term goal of this program is the establishment of an independent business unit engaged in the field of orthophotos image sensing for the purposes of utilization in agriculture, health, territorial mapping, mining, and industrial and governance industries requiring sensing results taken from the upper side of the object. For application development, agile methodology is used, while business-side planning use business model canvas and SWOT analysis. With the geospatial orthophotos, it is possible to identify which part of the plantation land is fertile for planted crops, means to grow perfectly. It is also possible furthermore to identify less fertile in terms of growing but not perfect, and also part of plantation field that is not growing at all. This information can be easily known quickly with the use of UAV photos. The resulting orthophotos image were processed using Matlab including classification of fertile, infertile, and dead palm oil plants by using Gray Level Co-Occurrence Matrix (GLCM) method. From the results of research conducted with 30 image samples, it was found that the accuracy of the system can be reached by using the features extracted from the matrix as parameters Contrast, Correlation, Energy, and Homogeneity.
\end{abstract}

Keywords: UAV, image processing, plantation

\section{INTRODUCTION}

Remote sensing based on Unmanned Aerial Vehicles (UAV) is used to obtain farm land data quickly and easily to obtain information on vegetation conditions with precision results. This technology is growing rapidly due to the enormous benefits and advantages in the management of agricultural resources, especially to study the health of vegetation. Multispectral data obtained using a camera mounted on the UAV in the form of drones that air during some time. Multispectral data is processed with photogrammetry to create orthophotos from the surveyed field. The ortophotos are then used to extract some Vegetation Indexes such as Normalized Differences Vegetation Index, Green
Vegetation Difference Normal Index, and Soil Absorption Vegetation Index. Namely the test to see the health condition of each plant. One example of sensing results using a UAV on agricultural land can be seen in Figure 1.

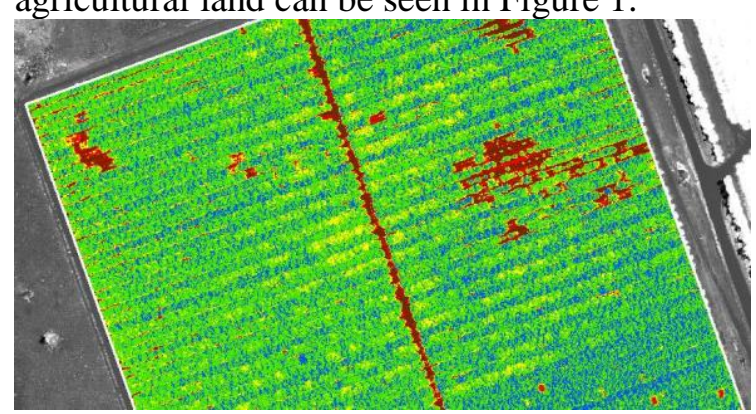

Figure 1. Sensing result of agriculture land

Further research in this area is on the speed of image processing of sensing result using 
limited computing resources so as to produce more economical product.

The impacts and benefits of these products and services for the socio-economic community are through the analysis of appropriate sensing results, the plant management can quickly anticipate the less healthy plants to be given special treatment.

With the vast territory of Indonesia and the potential of agricultural land and plantation as shown in Figure 2, the prospect of analyzing the image of vegetation using orthophotos is still wide open.

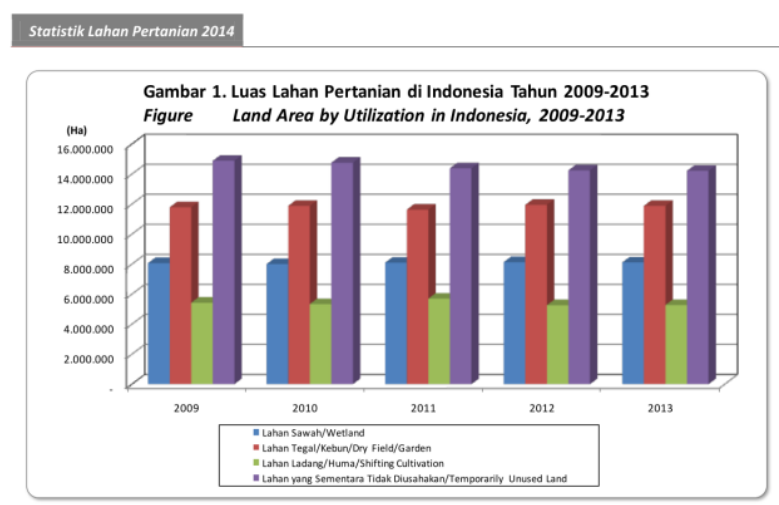

Figure 2. Statistic of farmland in Indonesia (sumber: Kementerian Pertanian Republik Indonesia)

In this study, we utilized Unmanned Aerial Vehicle (UAV) to get geospatial orthophotos for monitoring oil palm plantations. The aim is to check the growth of oil palm plants from the beginning, in order to identify which part of the plantation land is fertile for planted crops which mean to grow perfectly, less fertile in terms of growth but not perfect, or not growing at all. This information can be known quickly by the using of UAV geospatial orthophotos.

The purpose of this study was to develop an orthophotos image analysis for monitoring vegetation within palm oil plantation. The aim is to automatically measure the area of palm oil plantation and classify it into three categorize : fertile, nonfertile and no grow area.

\section{MATERIAL AND METHODS}

Image processing today has a vast spectrum of applications in various fields of life including in the fields of biomedicine [1], astronomy, archeology, biometrics [2], daily life [3,4] image and document archives, industry and remote sensing using satellite imagery technology[5] .

Utilization of satellite imagery has been done mainly to identify changes in shape, extent or other conditions of a specific region. In this study, we utilized Unmanned Aerial Vehicle (UAV) to get geospatial orthophotos for monitoring oil palm plantations. The aim is to check the growth of oil palm plants from the beginning, in order to identify which part of the plantation land is fertile for planted crops which mean to grow perfectly, less fertile in terms of growing but not perfect, or not growing at all. This information can be known quickly by the using of UAV geospatial orthophotos.

In previous research conducted by Rizatus Shofiyanti (2011) [6], they utilized the image of UAV for indraja application for monitoring agricultural land. Muhammad Rendana et al. have established a system to detect palm oil nutrient stress, and Salim Malek (2014) examines the UAV image to detect palm oil rods $[7,8]$.

A UAV or an unmanned aircraft is an unmanned flight or a glyph which can be controlled by a remote control or even with autonomous self-control. Unmanned drone controls are two main variants, the first variation being controlled via remote control and a second variation is a plane that flies independently according to the program included before flying [9].

An orthophoto is a kind of photographic map, which is quite possible to perform measurements as if it were a standard map. It is part of the photogrammetry field and is generally performed by Unmanned Aerial Vehicles (UAV). The resulting orthoimage can be synchronized with other maps containing other urban or technical elements such as agriculture or plantations, power grids, dams, etc. Example of orthophotos can be seen in Figure 1.

Geospatial or geo-space is a spatial aspect which indicates the location and position of an object or event that is under or on the surface of the earth expressed in a particular coordinate system. Geospatial data is data about geographic location, dimension or size, and / or characteristic of natural and / or man- 
made objects located below or on the surface of the earth [10].

Image or photo interpretation is an action to examine a photographic image for the purpose of identifying the object and assessing the significance of the image or photograph. Image interpretation is a process of recognizing objects in the form of images (images) for use in certain disciplines such as geology, geography, and other disciplines (Figure 3).

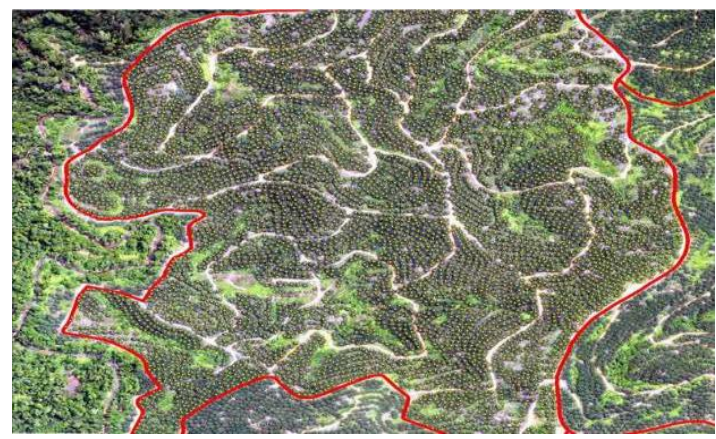

Figure 3. Example of Orthophotos mapped by UAV

Digital image processing is work to process and analyze a digital image that involves a lot of image data in the form of pixel representation. The stage of preprocessing is part of the preparation for digital image processing to be analyzed later on. Several methods can be done as part of the preparation of the image in accordance with the needs of the next process.

The success of this activity depends on orthophotos as a result of sensing using UAV on farmland and plantation.

Currently owned production capital is the source of knowledge in the form of books and some units of computer owned by faculty and personal use to process the image on a small scale. For larger scale or enterprise we will need much more powerful computing resources. The choice is to use a server cluster physically administered independently or rent cloud computing.

For the manufacture of orthophotos processing and analysis applications as well as guarantor of product quality, we use the Agile methodology as shown in Figure 4.

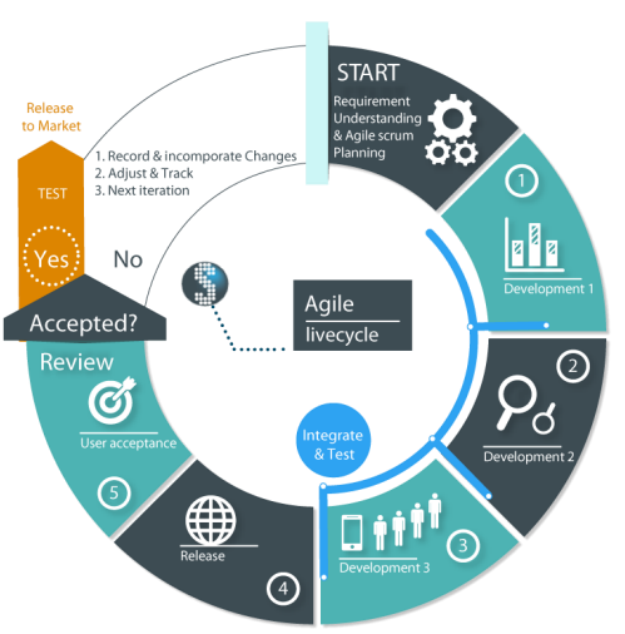

Figure 4. Agile Software Development Lifecycle (sumber: www.linkedin.com)

As a partner, PTPN IV was involved in the development. PTPN IV is a company which engages in the business of agro-industry as a state-owned plantation company with oil palm plantations in the Saribu Dolok Simalungun area. PTPN IV cultivates plantations and processing of palm oil and tea that includes the processing areal and crops, nurseries and maintenance of generating plants, processing the commodities into various industrial raw materials, marketing of produced commodities and other supporting activities. PTPN IV has 30 business units that manage the cultivation of palm oil and 1 Business Unit which manages the cultivation of tea and 1 Unit Plasma Estate Palm Oil, and 1 Business Unit Workshop (PMT Dolok Ilir) spread in 9 districts, namely Langkat, Deli Serdang, Bedagai Serdang, Simalungun, Asahan, Labuhan Batu, Padang Lawas, Coal and Mandailing Natal.

\section{RESULTS}

a. Preparation of Orthophotos Imagery Image data retrieval is done by UAV / Drone type DJI 3 type Phantom (Figure 5)

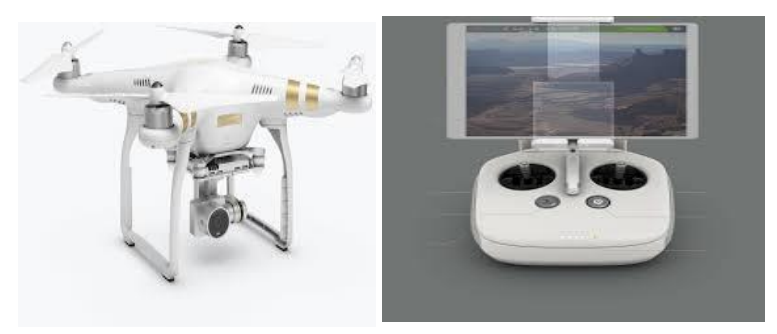


Figure 5. UAV type Drone DJI 3 Phantom and remote control
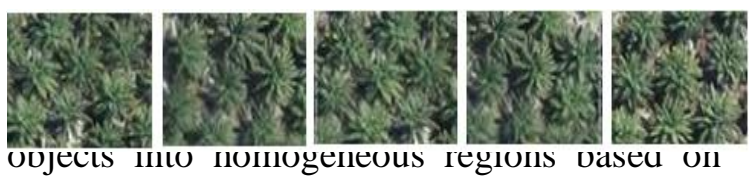

tegions vasea on

the similarity between the gray level of a pixel to the gray level of its neighboring pixels.

This step is included in the Feature Extraction

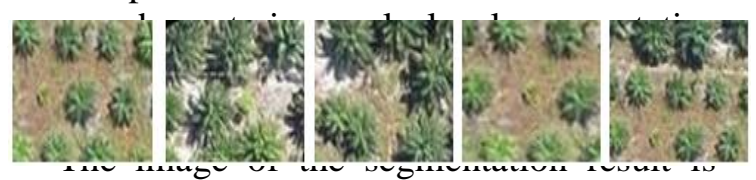

then extracted by the Gray Level Cooccurrence Matrix (GLCM) method, for each class of the object / segment that has been formed from the segmentation. GLCM is a matrix whose elements are the number of pixel pairs that have a certain degree of brightness, in which the pixel pair is separated by a distance $\mathrm{d}$, and with an inclination angle $\theta$ [11]. The wide of specific area will automatically be determined when UAV / Drone is flown to retrieve image data from oil palm plantations.

Classification is done by first input sample data for palm oil image in fertile category 10 sample, less fertile 10 sample and not grow 10 sample as the training set. The threshold value was obtained from the training session and then used as a parameter to classified the unknown area $[15,16]$. From the sample tested, it will be calculated are based on four features: Energy, Correlation, Contrast, and Homogeneity [17].

The palm oil image data obtained from the drone type DJI phantom type is shown in Figure 6.

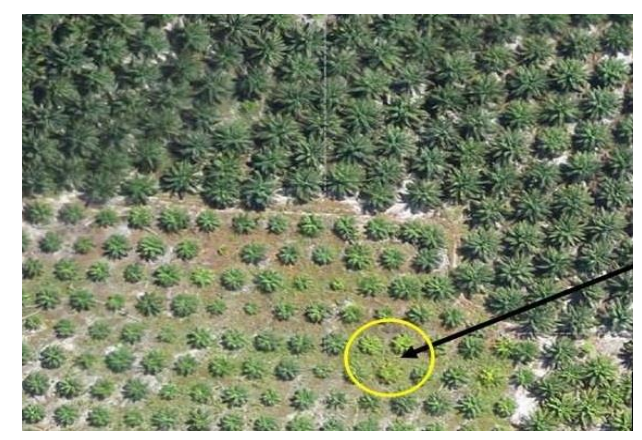

Figure 6. Palm oil Plantation captured by Drone
Examples of palm oil image for fertile, less fertile and not growing are shown in Figure $7 \mathrm{a}, \mathrm{b}$ and $\mathrm{c}$.

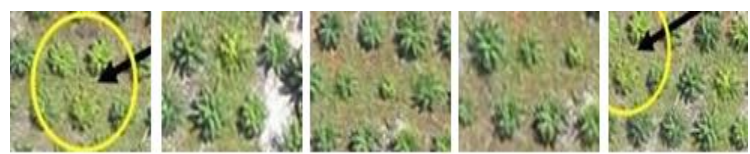

Figure 7. Palm oil Area (a) Fertile, (b) Less Fertile and (c) Not Growing

After the image data was cropped, the image will be changed into a matrix form that collects the pixel color of the gray image data and the direction value of the degree of image grayscale with 4 categories. From the research that has been done, it can be concluded that the use of UAV for monitoring of oil palm can identify the fertile area, less fertile and not grow automatically. The application can be made using GLCM method. From the results of research conducted with 30 image samples, it was found that the accuracy of the system can be reached by using the features extracted from the matrix as parameters Contras, Correlation, Energy, and Homogeneity [17].

\section{CONCLUSION}

The use of UAV for monitoring of oil palm can identify the fertile area, less fertile and not grow automatically. The long-term goal of this program is the establishment of an independent business unit engaged in the field of orthophotos image sensing for the purposes of utilization in agriculture, health, territorial mapping, mining, and industrial and governance industries requiring sensing results taken from the upper side of the object. Within a period of three years planned, it is expected that this business unit can be financially independent by becoming a trusted consultant and producing a qualified application product. 


\section{ACKNOWLEDGEMENT}

This study is supported by LPPM University of Sumatera Utara through the IBKIK Program in year 2017. We thank also for the support from PTPN IV Medan during the study.

\section{REFERENCES}

[1] Fahmi, Fahmi, et al. "3D movement correction of CT brain perfusion image data of patients with acute ischemic stroke." Neuroradiology 56.6 (2014): 445-452.

[2] Siswanto, Antonius, Pernantin Tarigan, and Fahmi Fahmi. "Design of contactless hand biometric system with relative geometric parameters." Instrumentation, Communications, Information Technology, and Biomedical Engineering (ICICI-BME), 2013 3rd International Conference on. IEEE, 2013.

[3] Triantoro, Teguh, F. Rizal Batubara, and F. Fahmi. "Image based water gauge reading developed with ANN Kohonen." Electrical Engineering and Computer Science (ICEECS), 2014 International Conference on. IEEE, 2014

[4] Muhammadiy, Wasfi, and Fahmi Fahmi. "Mobile application to differentiate flesh meat between beef and pork." Computational Intelligence and Cybernetics (CYBERNETICSCOM), 2016 International Conference on. IEEE, 2016.

[5] Tarigan, A. P. M., et al. "Mapping a Volcano Hazard Area of Mount Sinabung Using Drone: Preliminary Results." IOP Conference Series: Materials Science and Engineering. Vol. 180. No. 1. IOP Publishing, 2017.

[6] R. Shofiyanti, "Teknologi Pesawat Tanpa Awak untuk Pemetaan dan Pemantauan Tanaman dan Lahan Pertanian," Inform. Pertan., vol. 20, no. 2, pp. 58-64, 2011.
[7] O. Guldogan, J. Rotola-pukkila, U. Balasundaram, T. Le, and K. Mannar, "Automated Tree Detection and Density Calculation using Unmanned Aerial Vehicles," Vcip2016, pp. 4-7, 2016.

[8] T. Moranduzzo and F. Melgani, "Monitoring Structural Damages in Big Industrial Plants With Uav Images," pp. 4950-4953, 2014.

[9] B. Emirul, "Drone 1.," pp. 1-19, 2015.

[10] J. J. Mitchell, N. F. Glenn, M. O. Anderson, R. C. Hruska, and A. H. Charlie, "Unmanned Aerial Vehicle ( UAV ) Hyperspectral Remote Sensing for Dryland Vegetation Monitoring Hyperspectral Image and Signal Sensing," 4th Work. Hyperspectral Image Signal Process., no. Ua V, 2012.

[11] Saifudin,Abdul Fadlil "Sistem Identifikasi Citra Kayu Berdasarkan Tekstur Menggunakan Gray Level Cooccurrence Matrix (Glcm) Dengan Klasifikasi Jarak Euclidean",ISSN: 1410233

[12] Hepi Handayani, MariaRegina Caeli, " Studi Perhituungan Jumlah Pohon Kelapa Sawit Menggunakan Metode Klasifikasi Berbasis Obyek" Publication at https://www.researchgate.net/publication/ 311770484, October 2016

[13] T. Acharya and A. K. Ray, "Image Processing: Principles and Applications," pp. 1-3, 2005.

[14] E. C. Pengolahan et al., "Praktikum ec4041 pengolahan citra dan pengenalan pola ec6041 pengolahan citra dan pengenalan pola lanjut modul 3 - analisis tekstur," pp. 1-13.

[15]S. Kusumadewi, "Jaringan Syaraf Tiruan menggunakan MATLAB \& EXCEL LINK," in Komputasi dan Sistem cerdas, 2004th ed., vol. 1, GRAHA ILMU, 2004, p. 408. 